\title{
The Preauricular Sinus / Cyst: A Case Report
}

\section{Preauriküler Sinüs/Kist: Olgu Sunumu}

\author{
Nazim Bozan ${ }^{1, *}$, Yunus Feyyat Sakin ${ }^{2}$, Ahmet Gözen $^{3}$, Ferhat Bozkuş $^{4}$ \\ ${ }^{1}$ Department of Otorbinolaryngology, Yuгuncu Yil University Faculty of Medicine, Van, Turkey \\ ${ }^{2}$ Department of Otorbinolaryngology, Diyarbakur Training and Reseaarch Hospital, Diyarbakerr, Turkey \\ ${ }^{3}$ Department of Pediatric Surgery, Lokman Hekim Hospital, Van, Turkey \\ ${ }^{4}$ Department of Otorbinolaryngology, Harran University Faculty of Medicine, Şanliurfa, Turkey
}

\begin{abstract}
Preauricular sinus is a congenital anomaly that occurs because of a malformation during the merging of first and second branchial clefts, which form the ear in the course of embryonic development. Although it is usually nonsymptomatic, it can rarely be seen together with recurrent swelling and discharge, and inflammatory infections. A preauricular sinus was observed in front of the right ear of an 18-year-old male patient with a recurrent swelling and wound infection for 3 years; and the case was discussed in the guidance of the literature. It would be important to consider preauricular sinus as the basis of recurrent swelling and inflammatory skin infections and wounds of the preauricular region, which do not respond to treatment nor heal. Recurrence may take place in the late period, in case of an inadequate resection of the fistula tract. Preauricular sinus/cyst should be taken into account in differential diagnosis of preauricular region lesions.
\end{abstract}

Key Words: Congenital preauricular fistula, preauricular cyst, preauricular sinus, surgical approach

\section{Introduction}

Congenital preauricular lesions are malformations that are classified as preauricular sinus and first branchial cleft anomalies seen frequently during childhood (1). Preauricular sinus (PAS) is an epithelial cyst or sinus formation that occurs on the facial skin in front of the ear. This defect is a congential anomaly that occurs because of a failure in merging of the first and second branchial cleft that forms the ear. Typically, it is in the form of a small hole, placed in front of the tragus and helix, with a tract extending inwards. It also has a sinus, coated with a multilayer flat epithelium, with no skin appendages (2). These

\begin{abstract}
ÖZET
Preauriküler sinüs embriyonik gelişimde kulağ1 oluşturan birinci ve ikinci brankial yarı̆̆ın birleșmesi sırasında meydana gelen bozukluk onucu oluşan konjenital bir anomalidir. Genellikle semptomsuz olup, nadiren tekrarlayan rekürren şişlikle beraber akıntı, üzerinde inflamasyon meydana gelen ve enfeksiyonlarla bir arada olabilmektedir. Sağ kulak önünde 3 yıldır tekrarlayan rekürrent şişlik ve yara enfeksiyonu bulunan 18 yaşındaki erkek hastada preauriküler sinüs saptandı ve literatür eşliğinde vaka tartışıldı. Özellikle preauriküler bölgenin iyileşmeyen ve tedavilere cevap vermeyen tekrarlayan rekürren şişlikle beraber akıntı, üzerinde inflamasyon meydana gelen deri enfeksiyonu ve yaralarının emininde preauriküler sinüsün de olabileceği unutulmamalıdır. Fistül traktusunun yetersiz rezeke edildiği vakalarda geç dönemde nüks meydana gelebilmektedir. Preauriküler sinüs/kist preauriküler bölge lezyonlarında ayırıcı tanıda düşünülmelidir.
\end{abstract}

Anahtar Kelimeler: Konjenital preauriküler fistül, preauriküler kist, Preauriküler sinüs, cerrahi yaklaşım

anomalies, which have similar clinical symptoms and surgical treatment, may be in form of a cyst, sinus or a fistula, with an incidence rate of 0.1 $0.9 \%$ (1). They are usually asymptomatic and rarely seen together with chronic wound infections, which might lead to a misdiagnosis (3). Thirty-five to fifty percent of the cases are bilateral (1). Three theories are often mentioned about etiopathogenesis. The most widely accepted one suggests that the anomaly occurs because of incomplete or defective fusion of the auricular trabeculae during embryogenesis.

Another one weighs on the causality of the incomplete closure of the dorsal part of the first pharyngeal groove, which might lead us to the 
idea that preauricular lesions are actually branchiogenic malformations. According to the third theory, these lesions arise from the inward folding of the ectoderm during the auricular development (4). Various methods are defined for the surgical treatment of preauricular fistulas. The most commonly used is the dissection of the tract with methylene blue or probe guide, following the elliptical incision. As it is well known, the main reason for a recurrence is the incomplete resection of the preauricular cyst and and fistulas $(1,4)$.

\section{Case Report}

An 18-year-old patient presented to our clinic with complaints of recurrent swelling and discharge, along with incrustation, on the right preauricular region. The symptoms started almost 3 years ago and lessened in time with antibiotic treatment, but never disappeared. He also stated that he did not have any ear pain or hearing loss, but he presented to the clinic on account of occasional swelling and a small hole in front of the right ear. When we examined him, we located a soft, painless swelling and a preauricular sinus that presented as a small hole with a fistula orifice before the helix and superior to the tragus, in the right preauricular region (Figure 1). The findings upon facial nerve and mouth and pharynx examinations were normal and natural, with no signs of cervical lymphodenopathy. No additional pathologies were observed in other ear, nose, throat and system examinations. No other traits were observed in his or family history, either. The routine biochemical and hemogram analyses and lung radiography also proved to be normal. Probing and methylene blue injection was used during the surgery to ease the dissection of cyst tract in the patient with fistula. Fistulography showed us a cyst and a cyst tract in the preauricular region. The patient went under surgery via general anesthesia. Based on the diagnosis of preauricular fistula or cyst, an 18G needle, with its shaft removed, was inserted as a probe inside the fistula tract and fixed at the fistula entrance with a suture (Figure 2). Thereafter, the tract and the cyst were clearly marked by giving methylene blue injection through the needle.

After injecting methylene blue in the fistula tract, an elliptical incision was performed on the fistula orifice for the dissection of the tract. Supraauricular approach was preferred to allow for a wide exposure. By this, the elliptical incision was extended from the auricula anterior to superior and the resection was performed up to temporal fascia. The fistula tract was followed until the helix cartilage and excision was carried out.

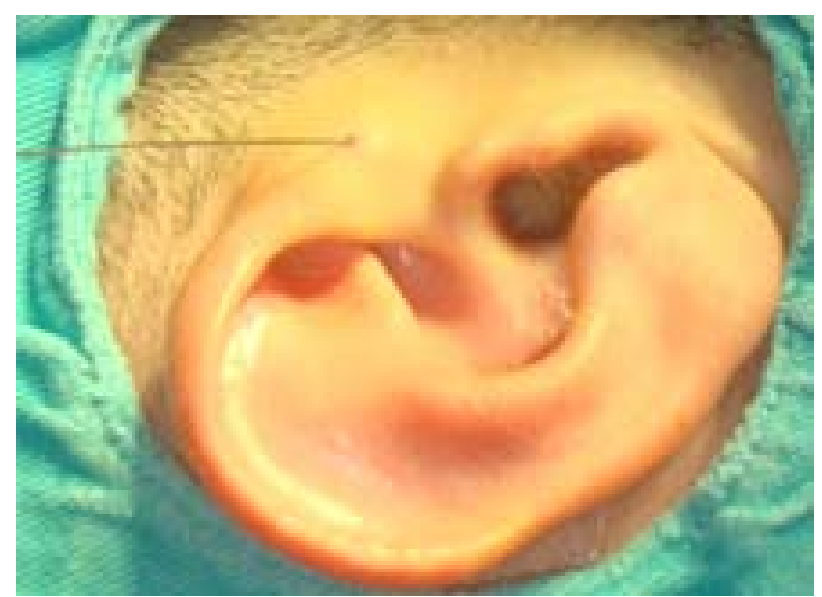

Fig. 1. Preauricular sinus presented as a small hole with a fistula orifice (Preauricular fistula orifice).

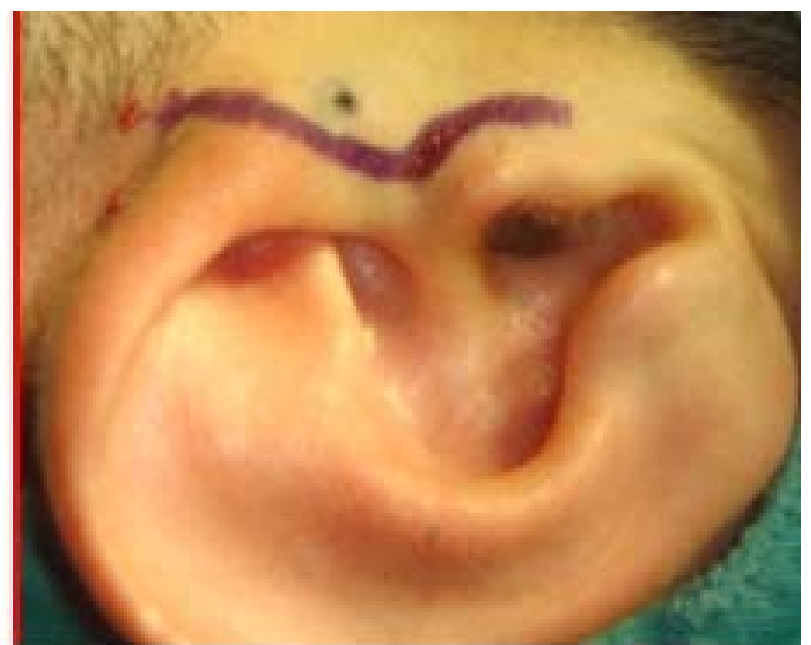

Fig. 2. Marking the tract and the cyst by giving methylene blue injection through the needle. 

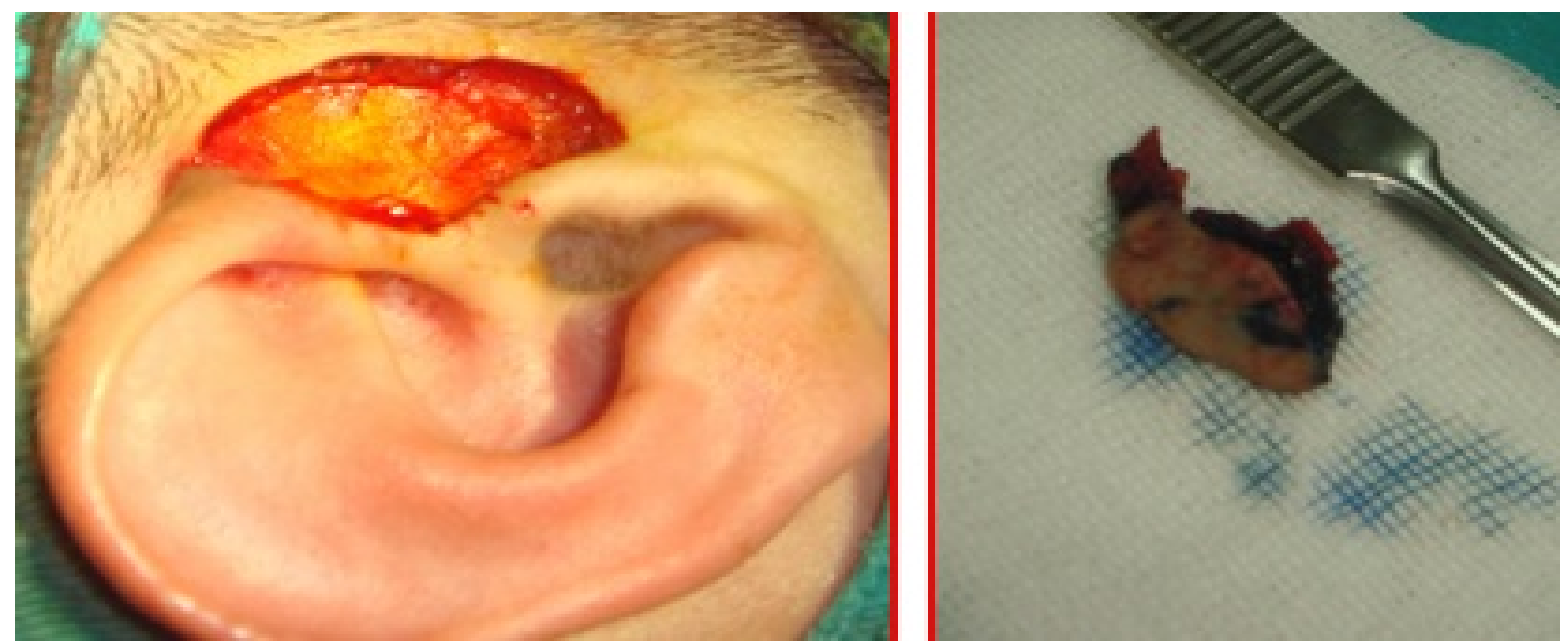

Fig. 3. Supra-auricular approach preferred for a wide exposure. The elliptical incision was extended from the auricula anterior to superior and the resection was performed up to temporal fascia (temporal fascia is shown). The fistula tract was followed until the helix cartilage and a total excision was carried out.

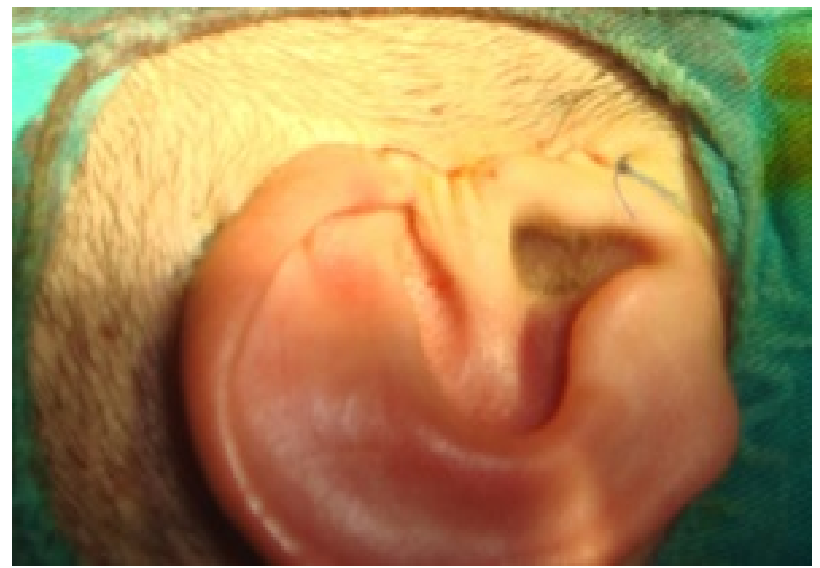

Fig. 4. Esthetic appearance achieved after the operation.

The section was later primary sutured after being washed with rifampicin solution. The preauricular fistula tract and the cyst were totally removed (Figure 3-4). The patient was orally given semisynthetic penicillin type prophylactic antibiotics after the operation. The patient was discharged the next day, with no post-operative symptoms. The pathology result of the specimen was the same as the pre-operative diagnosis and it was reported as "preauricular sinus". The patient was given informed consent for presentation of this case study. No recurrence was seen on the second and sixth month follow-ups.

\section{Discussion}

The preauricular sinus is a blind canal, positioned mostly in front of the tragus and the helix, and extends from the epidermis to subcutaneous tissues, being one of the frequently seen congenital ear anomalies (2). The etiology of preauricular sinuses and fistulas are not completely discovered, yet, they are thought of as congenital malformations, where either an embryological auricular development defect or a closure defect of the first pharyngeal cleft lies in the pathogenesis of. As their incidence rate varies between $0.1-0.9 \%, 30-50 \%$ of the preauricular lesions are bilateral (1). They have a single or multilocular sinus, usually ending with a deep, cystic formation that runs along the outer ear. They all occur outside the temporal fascia and never involves the tympanic membrane or external ear meatus (2). The preauricular lesions are mostly seen during childhood, as they are congenital malformations. Our patient was an 16-year-old male. The most widely accepted hypothesis suggests that these varying anomalies are equally seen in both sexes and they are autosomal dominant inheritances (5).

Several authors have reported that preauricular lesions could develop together with renal defects or other anatomical anomalies (6). Cremers have presented a case with a "mixed hearing loss", related with the tympanic cavity (7). However, our patient did not have other types of anatomical malformation and his audiometric tests returned results within limits.

Preauricular fistulas, can develop asymptomatically, as well as, in the form of a recurrent swelling, discharge or an abscess. Our patient presented to our clinic with complaints of recurrent swelling and discharge, along with incrustation, on the right preauricular region, 
which started almost 3 years ago and lessened in time with antibiotic treatment, but never disappeared. He also stated that he did not have any ear pain or hearing loss, but had occasional swelling and a small hole in front of the right ear.

These are usually asymptomatic. However, due to obstruction of the orifice, infection and abscess formations may rarely be observed. Recurring infections might, in time, lead to an ulcer in the region (4). Our patient have had a non-healing wound infection for two years and had a onesided PAS with a yellow-brown crust and surrounding erythema, in the right preauricular region. In preauricular fistulas with a first branchial cleft anomaly, the epithelial tract either opens out to the outer ear canal or is very close to it. In particular, Type II anomaly is locally positioned posterior, medial and inferior to the conchal cartilage. The fistula usually connects the skin with the outer ear canal and continues in parallel to the canal. It also tends to run on the lateral of the facial nerve. The anomaly occasionally places itself either just behind the angulus mandibula or under it. It has a close relationship with the parotid gland and the facial nerve. The tract might go upward through the parotid gland, or may take place on the lateral, medial to or between branches of the facial nerve. It will usually open out to the outer ear canal at the junction of the cartilage and the bone, and rarely to the middle ear. For a full excision of the preauricular fistulas, it might be essential to reveal the facial nerve branches at times (8).

The standard is to dissect the tract by performing an elliptical incision around the fistula. However, total removal of the tract is much crucial in order to prevent further recurrences (1). A rate of $5-42 \%$ for recurrence has been reported in the literature $(1,8)$. Many authors recommend methylene blue to mark out the fistula tract (1). Methylene blue helps to dye the epithelial tract and get rid off epithelial residues. Nonetheless, the "tattooing effect" of the methylene blue is an undesired postoperative complication. In our case, methylene blue proved to be of much guidance, especially in the deeper plane dissection.

In the differential diagnosis of the preauricular sinus, a wide range of diseases, such as pyogenic skin infections, atypical microbacterial infections and cutaneous tuberculosis, pyogenic granuloma, suppurative lymphadenitis, actinomycosis, thyroglossal duct cyst, dental sinus, branchial cleft cyst, salivary gland fistulas, osteomyelitis of the facial bones, reactions to foreign objects, infected pilar cyst, epidermal inclusion cyst, syphilitic gum, and squamous-cell and other types of skin carcinomas take place (9). Much like in our case, a thorough analysis, physical examination by palpation and a radiographic inspection is essential to reach a definite conclusion in recurring chronic wounds despite medical treatment and diagnose it as "preauricular sinus".

In our case, we used this method to prevent a recurrence and performed dissection in a broad region. We also cared for the esthetic appearance of the patient, considering his young age, and achieved good results.

Most of the preauricular sinuses do not show symtptoms for a life time and do not need a treatment. Preauricular sinus infection develops in few patients, and after the symptoms are observed, the sinus tract is clearly marked out and the patient is advised for a surgical excision (6). Inadequate excisions often lead to recurrences (10). We did not observe any recurrence on the second and sixth month follow-ups. As depicted in this study, we should keep in mind that PAS might lie beneath the chronic wounds, infections and lesions, unresponsive to treatments and placed on the front of the ear; and the patients' examinations and treatments should be carried out accordingly.

Preauricular sinuses are congenital development defects and require surgical treatment. In case of inadequate resection of the fistula tracts, recurrences may be seen in a later period. The skin inflammation and furuncles in the preauricular region are related to preauricular sinus. The physical examination of the sinus should be performed attentively. Excision should be carried out when the infection is not severe. The procedure is not an easy one, it may although seem as a minor surgery. The long, branched and lobular lesion should be excised. Partial removal of the sinus tract shall lead to future infection and need of a revisional surgery.

To guarantee a precise excision of the preauricular sinus, the endaural incision should be done wide enough to see the temporal fascia, as shown in the picture. Methylene blue can be injected to observe the cyst better; thus, we can be sure of a total removal. The cyst should be dissected from the surface toward to sinus opening and the skin of the sinus opening should be removed elliptically.

\section{References}

1. Martin-Granizo R, Perez-Herrero MC, SanchezCuellar A. Methylene blue staining and probing 
for fistula resection:application in a case of bilateral congenital preauricular fistulas. Int J Oral Maxillofac Surg 2002; 31(4): 439-441.

2. Walner DL, Myer CM. Salivary gland disease. İn: Cumings CW, Fredrickson JM, Harker LA, Krause CJ, Richardson MA, Schuller DE, editors. Pediatric otolaryngology head and neck surgery. 3rd ed. St Louis, MO: Mosby, 1998: 116-132.

3. Moreland RF, Elston DM. Photo quiz. Preauricular pit. Cutis 2001; 68(5): 324.

4. Aronsohn RS, Batsakis JG, Rice DH, Work WP. Anomalies of the first branchial cleft. Arch Otolaryngol 1976; 102(12): 737-740.

5. Bhalla V, Roy S, Inam AS. Familial transmission of preauricular fistula in a seven generation Indian pedigree. Hum Genet 1979; 48(3): 339341.
6. Leung AKC, Robson WLM. Association of preauricular sinuses and renal anomalies. Urology 1992; 40(3): 259-261.

7. Cremers CW. Congenital preauricular fistula communicating with the tympanic cavity. J Laryngol and Otol 1983; 97(8): 749-753.

8. Osma Ü. Dış Kulak Hastalıkları. In: Koç C, editor. Kulak burun boğaz hastalıkları ve başboyun cerrahisi, Ankara: Güneş Kitabevi, 2004: 110-127.

9. Palacio JE, Altemus DA, Christensen ED, Sorensen GW. Unusual recurrent facial lesion. Arch Dermatol 1999; 135(5): 595-598.

10. Ahuja AT, Marshall JN, Roebuck DJ, King AD, Metreweli C. Sonographic appearances of preauricular sinus. Clin Radiol 2000; 55(7): 528532. 